\title{
Does FTO have a paradoxical effect in fetal life?
}

\author{
Olivier S Descamps ${ }^{1,2^{*}}$, Eric Tarantino ${ }^{1}$ and Pierre-Francois Guilmot ${ }^{3}$
}

\begin{abstract}
Background: Low weight at birth is associated with obesity in later life. One hypothesis to explain such an association is that genetic variants that increase the risk of obesity also reduce fetal weight. Recently, obesity in adults was found to be associated with common variants of the fat mass and obesity-associated (FTO) gene. We examined the association between FTO polymorphisms and birth weight in a singleton, full-term birth cohort of 494 newborn-mother pairs without any complications.

Results: The risk alleles for obesity ("A" allele for the rs9939609 FTO variant and "G" allele for the rs9930506 FTO variant) were associated with low weight at birth. The mean differences per risk allele were $-79 \mathrm{~g}$ ( $95 \% \mathrm{Cl}:-129$ to -30 ; $\mathrm{p}=0.002)$ for rs 9939609 and $-84 \mathrm{~g}(95 \% \mathrm{Cl}:-131$ to $-36 ; \mathrm{P}<0.001)$ for rs 9930506 . The level of association remained statistically significant after adjustment for the maternal risk allele and for variables usually associated with birth weight ( $-50 \mathrm{~g}, 95 \% \mathrm{Cl}$ : -99 to $0 ; p=0.05$ for rs 9939609 and $-48 \mathrm{~g}, 95 \% \mathrm{Cl}:-100$ to $0 ; p=0.05$ for rs 9930506 ). In the follow-up, the allelic difference in weight was attenuated over time.

Conclusions: The FTO variants that confer a predisposition to obesity later in life appear to be associated with low weight at birth. This finding favors the hypothesis of a common genetic denominator that predisposes to a low weight at birth and obesity in adults.
\end{abstract}

Keywords: Obesity, FTO, Newborn, Mother, Birth weight, Adiposity

\section{Background}

Low birth weight is associated with an increased prevalence of obesity and insulin resistance syndrome in adult life, leading to an increased risk of type 2 diabetes, hypertension, and cardiovascular disease [1-5]. Although the mechanisms for this association are unknown, researchers have proposed that it reflects fetal programming in utero in response to maternal malnutrition during pregnancy $[2,6,7]$. An alternative hypothesis [8] is that genetic variants that increase the risk of disease also reduce fetal weight.

Several independent, genome-wide, association studies have recently identified a strong correlation between fat mass and obesity-associated (FTO) polymorphisms and obesity-related parameters (body mass index [BMI], total body weight, and hip circumference) in adults and children [9-11]. In childhood, although the known FTO risk alleles

\footnotetext{
* Correspondence: olivierdescamps@hotmail.com

${ }^{1}$ Center for Medical Research at Jolimont, 159 Rue Ferrer, B-7100 Haine

Saint-Paul, Belgium

${ }^{2}$ Department of Internal Medicine, Centre Hospitalier Jolimont-Lobbes, 159

Rue Ferrer, B-7100 Haine Saint-Paul, Belgium

Full list of author information is available at the end of the article
}

for obesity are associated with an increased BMI in the postnatal period [12], they have no effect on birth weight. This conclusion was drawn from large cohorts that were not controlled for situations affecting birth weight, such as gestational diabetes [13] or other gestational complications. In the present study, we investigated the effect of two common FTO polymorphisms on birth weight in a singleton, full-term birth cohort without any maternal or newborn complications.

\section{Methods}

\section{Study design}

The mothers and their newborns were consecutively recruited in the maternity ward during 2008 and 2009. The nurses of the maternal unit collected blood samples (cord blood) and recorded maternal (at entry) and newborn (at delivery) anthropometric parameters. Birth weight was measured to the nearest $1 \mathrm{~g}$ using a digital baby scale Seca model 727 (Seca Belgium, Zwijndrecht), which includes a special damping system that allows for precise weighing, even if the newborn is restless. Two trained study nurses extracted data (parity, weight measured at the first antenatal clinic, and gestational age estimated from 
early obstetric ultrasound) from the obstetric medical records and interviewed the mothers to obtain data on smoking status and the genealogical tree (four generations).

The selection criteria of the mother-newborn pairs were a Caucasian origin, eutocic delivery with cephalic presentation between the beginning of the 37th week and the end of the 41st week, singleton live birth, no maternal use of alcohol or illicit substances, no gestational complications, no diabetes, no congenital malformations or perinatal problems, and an Apgar score of $\geq 7$ during the 1 st minute and $\geq 9$ by the 5 th minute. Twenty-nine of the original mother-newborn pairs who were recruited by the nurses were excluded because of non-compliance with one or more inclusion criteria, difficulty of genotyping, or important missing data.

For infants participating in the follow-up program of our hospital, body weight at 3, 6, 9, and 12 months was collected from the pediatric medical records. For the other children, we attempted to obtain data 1 year later by phone for the most recent weight of the child. The study protocol was approved by the Ethical Committee of the Hospital of Jolimont (ECO22) and informed written consent was obtained from all mothers before participation.

\section{Genotyping}

We examined two single nucleotide polymorphisms (SNPs) of FTO (SNPs with the A risk allele for rs9939609 and the $G$ allele for rs9930506) that were previously shown to be strongly associated with obesity-related parameters in large European populations [9,14]. We were particularly interested in the G allele for rs9930506 because it shows an even stronger association in Sardinian and Italian populations $[15,16]$ and because some infants born in our hospital are partially of Italian descent (third or fourth generation born in Belgium). Genotyping of rs9930506 and rs9939609 was performed by Restriction Fragment Length Polymorphism-Polymerase Chain Reaction and Allele-Specific Oligonucleotide-Polymerase Chain Reaction, respectively, with a success rate greater than $97.5 \%$.

\section{Estimation of sample size}

Sample size was estimated for testing the primary hypothesis that birth weight is different between newborns with different genotypes (BMI was not used because measurement of length is less reliable in newborns). Based on the weights obtained in the first 100 newborns (mean \pm standard deviation: $3284 \pm 347 \mathrm{~g}$ ), the minimum size for each group that was required to detect a $5 \%$ difference (a priori considered as relevant) was estimated as 70, for a two-sided significance level of 0.05 and a statistical power of $80 \%$ [17]. Based on the minor allele (the "risk allele") frequency obtained in the first 100 newborns (approximately 40\% for both SNPs) and assuming
Hardy-Weinberg equilibrium, we set our target size to a minimum of 447 mother-newborn pairs.

\section{Statistical analysis}

The analyses focused on birth weight. We examined associations separately for newborn and maternal genotypes, and then mutually adjusted one for the other, as well as for other non-genetic factors using multiple linear regression analysis (SPSS for Windows, version 8.0). Adjustment for maternal genotype is important because of the strong association between maternal and newborn genotypes and our aim to establish whether any associations are primarily driven by newborn genetic variants independent of maternal genotypes. Other non-genetic factors that are known to affect birth weight were examined, including racial/ethnic origin (all subjects were Caucasians but some were of Italian origin), sex, gestational age, parity, cigarette smoking, maternal BMI, and weight gain during pregnancy. In all analyses, a perallele additive genetic model was examined.

\section{Results}

The characteristics of the newborns and their mothers are shown in Table 1. The risk allele frequencies were 0.41 for rs9939609 and 0.43 for rs9930506, similar to those reported in European cohorts (0.40 [9] and 0.44 [15]), in Flanders (0.41 for rs9939609 [18]), in Italians (0.48 and $0.50[16])$, and in Sardinians (0.46 and 0.46 [15]) (Table 2). There was no evidence of departure from the Hardy-Weinberg equilibrium (Table 2) or an association with the number of Italian great-grandparents (data not shown).

\section{Association of newborn FTO and birth weight}

For both SNPs, newborn homozygotes for the risk allele weighed significantly less than newborn heterozygotes, and weighed even less than the homozygotes for the non-risk allele, with a clear gene-dose effect (Table 3). The newborn risk alleles were associated with a lower birth weight, with a mean difference per risk allele of $-78 \mathrm{~g}$ (95\% confidence interval $[\mathrm{CI}]$ : -128 to $-28 ; \mathrm{p}=0.002$ ) for rs9939609 and -83 g (95\% CI: -131 to $-36 ; p=0.0006)$ for rs9930506. The level of association did not change when we adjusted for the maternal risk allele (Table 3). Low birth weight was associated with maternal risk alleles in univariate analyses (Table 4), but this association may have been attributed to the offspring's FTO gene because it was not more significant after adjustment for newborn risk alleles.

Birth weight was correlated with sex $(r=0.15, p=0.001)$, gestational age $(\mathrm{r}=0.33, \mathrm{p}<0,001)$, parity $(\mathrm{r}=-0.09$, $\mathrm{p}=0.06)$, cigarette smoking $(\mathrm{r}=-0.26, \mathrm{p}<0.001)$, and maternal BMI $(\mathrm{r}=0.17, \mathrm{p}<0.001)$, but not with Italian origin of the grandparents $(\mathrm{r}=-0.06, \mathrm{p}=0.21)$. There was only a 
Table 1 Characteristics of the newborns and their mothers

\begin{tabular}{|c|c|c|}
\hline Characteristics & Eligible data & Values \\
\hline Boys, N(\%) & 494 & $243(49 \%)$ \\
\hline Weight, $g$ & 494 & $3251,8 \pm 383,6$ \\
\hline Lenght, $\mathrm{cm}$ & 494 & $50,1 \pm 2,0$ \\
\hline Head circumference, cm & 494 & $34,0 \pm 1,4$ \\
\hline $\mathrm{BMI}, \mathrm{kg} / \mathrm{m}^{2}$ & 494 & $13,0 \pm 1,1$ \\
\hline Ge stational age, weeks & 494 & $39,1 \pm 1,2$ \\
\hline Mothers characteristics & 494 & \\
\hline Nullipara, N(\%) & 494 & 191(39\%) \\
\hline Smoking during pregnancy, N(\%) & 494 & $101(20 \%)$ \\
\hline Age, years & 494 & $28,7 \pm 5,4$ \\
\hline Height, $\mathrm{cm}$ & 494 & $164,7 \pm 6,1$ \\
\hline Weight before delivery, kg & 494 & $80,0 \pm 14,8$ \\
\hline BMI before delivery, $\mathrm{kg} / \mathrm{m}^{2}$ & 494 & $29,45 \pm 5,02$ \\
\hline Weight at pregnancy diagnosis, kg* & 486 & $67,2 \pm 15,4$ \\
\hline Calculated gain in pregnancy, kg** & 486 & $12,8915,4$ \\
\hline Weight after delivery, kg & 450 & $73,0914,6$ \\
\hline Calculated loss after delivery, $\mathrm{kg}^{*}$ & 450 & $-7,0 \pm 2,2$ \\
\hline Genealogical data & 485 & \\
\hline 0 Italian Great-grandparents, N(\%) & & $278(57 \%)$ \\
\hline 1-2 Italian Great-grandparents, N(\%) & & $62(13 \%)$ \\
\hline 3-4 Italian Great-grandparents, N(\%) & & $73(15 \%)$ \\
\hline 5-6 Italian Great-grandparents, N(\%) & & $27(6 \%)$ \\
\hline 7-8 Italian Great-grandparents, N(\%) & & $45(9 \%)$ \\
\hline
\end{tabular}

*self reported or unstandardized.

**calculated from self reported or unstandardized data on weight at pregnancy diagnose.

trend toward statistical significance with weight gain during pregnancy $(r=0.07, p=0.13)$. None of these factors was significantly associated with the risk alleles. In particular, maternal BMI was not significantly associated with newborn risk alleles, but it was significantly associated with maternal risk alleles $(\mathrm{p}=0.03$ for maternal rs9930506 and $\mathrm{p}=0.01$ for the maternal rs9939609). Additionally, maternal risk alleles were associated with newborn risk alleles. Adjustment for factors that were significantly $(\mathrm{p}<0.05)$ associated with birth weight (sex, gestational age, parity, current smoking during pregnancy, and maternal $\mathrm{BMI}$ ) only slightly decreased the strength of the associations between newborn risk alleles and birth weight, without affecting the statistical significance (Table 3). These associations were not modified by inclusion of weight gain during pregnancy.

Comparison of weight between the genotypes in childhood There was no difference in weight between the genotypes 3 months after birth in the subsamples of children whose weight we could directly measure. There was also no difference in weight between the genotypes 1 year after birth in the 371 infants for whom we could obtain information by phone (Table 5 ).

\section{Discussion}

In the present study, FTO variants that confer a predisposition to obesity later in life appeared to be associated with a low weight at birth. This association was not offset by an effect from the maternal genotype, as might have been expected through an effect of the same variants on maternal energy intake [19]. This association remained significant after adjustment for other possible confounders. These weight differences were rapidly attenuated after birth.

This is the first observation of such an inverse relationship between birth weight and FTO risk alleles for obesity in full-term, singleton, healthy newborns. An association between the more severe small-for-gestational age phenotype and risk alleles of FTO (odds ratio for SGA TA versus TT: 1.54; 95\% CI: 1.07, 2.22], as well as for other risk alleles (PTER and KCNJ11, two high-risk alleles associated with obesity and diabetes in adults), has been found by Morgan et al. [20]. Other studies have also shown a similar link between the genetics of type 2 diabetes with low birth weight [21-25] or with small-forgestational age [26,27]. In contrast, the first study to show an association between FTO and obesity [13], as well as other studies [12,28-31] and a meta-analysis by Kilpelainen et al. [32] (data from previous studies plus analyses of 4 large European birth cohorts), found no inverse association between the FTO risk allele and birth weight or evidence of a positive association by the postnatal age of 2 weeks (12]. In the meta-analysis by Kilpelainen et al. [32], among the 13 established risk alleles for obesity in various genes, only FTO (rs1121980) and MTCH2 (rs10838738) risk alleles were significantly associated with a high birth weight $(+11 \pm 4$ g/allele; $\mathrm{p}=0.013 ; \mathrm{n}=28,219)$ and low birth weight $(-13 \pm 5 \mathrm{~g} /$ allele; $\mathrm{p}=0.012 ; \mathrm{n}=23,680)$, respectively. None of these associations remained significant after correction for multiple testing. Many factors may explain the discrepancy between these studies and our study. Different populations are exposed to different environmental and genetic influences that may interact with FTO variants. Some of the cohorts in the meta-analysis [32] were born a long time ago (between 1918 and 1975), and most had a birth weight ranging from 3361 to $3536 \mathrm{~g}$, which is higher than that in our cohort and in newborns of European origin (3357 g) [33]. In some studies, data on birth weight were only selfreported, or reported by the participants' mothers, or sometimes measured, but rounded to the nearest quarter of a pound. These conditions decrease the power to detect significant associations. Furthermore, most studies had no information on gestational age, maternal DNA, or other 
Table 2 Frequencies of FTO genotypes and alleles

\begin{tabular}{|c|c|c|c|c|c|}
\hline FTO rs9939609 & & $\begin{array}{l}\text { Newborns with } \\
\text { TT genotype }\end{array}$ & $\begin{array}{l}\text { Newborns with } \\
\text { TA genotype }\end{array}$ & $\begin{array}{l}\text { Newborns with } \\
\text { AA genotype }\end{array}$ & HWE P value* \\
\hline Total & 494 & $167(34 \%)$ & $253(51 \%)$ & $74(15 \%)$ & 0.41 \\
\hline \multicolumn{6}{|l|}{ Maternal genotype } \\
\hline$\pi$ & $167(32 \%)$ & $95(57 \%)$ & $72(28 \%)$ & & \\
\hline TA & $248(50 \%)$ & $72(43 \%)$ & 133(53\%) & $43(58 \%)$ & 0.17 \\
\hline AA & $79(16 \%)$ & & $48(19 \%)$ & $31(42 \%)$ & \\
\hline FTO rs9930506 & & $\begin{array}{l}\text { Newborns with } \\
\text { AA genotype }\end{array}$ & $\begin{array}{l}\text { Newborns with } \\
\text { AG genotype }\end{array}$ & $\begin{array}{l}\text { Newborns with } \\
\text { GG genotype }\end{array}$ & HWE P value \\
\hline Total & 494 & $165(33 \%)$ & $236(48 \%)$ & $93(19 \%)$ & 0.57 \\
\hline \multicolumn{6}{|l|}{ Maternal genotype } \\
\hline AA & $155(31 \%)$ & $93(56 \%)$ & $62(26 \%)$ & - & \\
\hline$A G$ & $249(50 \%)$ & $72(44 \%)$ & $124(53 \%)$ & $53(57 \%)$ & 0.60 \\
\hline GG & $90(18 \%)$ & - & $50(21 \%)$ & $40(43 \%)$ & \\
\hline
\end{tabular}

${ }^{*}$ Chi-square test.

HWE: Hardy Weinberg equillibrium.

maternal/newborn characteristics that may confound the association. Finally, most previous studies did not exclude non-singleton births, individuals born preterm or post-term, gestational complications, or congenital malformations/perinatal problems. These factors are known to be associated with a greater prevalence of extreme birth weight.

Although replication in independent samples is essential, our finding is compatible with the hypothesis (also called the "fetal insulin hypothesis" [8]) that common genes that are inherited by the fetus affect birth size and predisposition to obesity, as well as its related complications in adult life [1-5]. How genetic variations in FTO contribute to variation in fetal weight may not be a simple explanation. In adults, the FTO gene is thought to contribute to weight gain by diminishing sensation of satiety and increasing energy and fat intake [34-36]. Such an explanation is not satisfactory in fetuses where the nutrients are completely provided by the maternal circulation. An indirect effect of the maternal FTO gene via a greater maternal energy intake is not conceivable because the maternal risk alleles were not independently associated with a low birth weight in our study. In the fetus, insulin is the main growth hormone and hyperor hypoinsulinemia can lead to macrosomia or growth retardation, respectively $[37,38]$. Several studies have

Table 3 Associations of birth weight and newborn FTO genotypes or alleles

\begin{tabular}{|c|c|c|c|c|c|c|}
\hline & \multicolumn{6}{|c|}{ Exposure $=$ Newborn FTO SNP } \\
\hline & \multicolumn{3}{|c|}{ Newborn weight (g) } & \multicolumn{3}{|c|}{ FTO rs9930506 SNP } \\
\hline & $\mathbf{N}$ & Mean $\pm S D(g)$ & $\mathrm{P}$ value vs $1^{\circ}$ group* & $\mathbf{N}$ & Mean $\pm S D(g)$ & P value vs $1^{\circ}$ group* \\
\hline \multicolumn{7}{|l|}{ Genotypes } \\
\hline Homozygous for non rish allele & 167 & $3314 \pm 378$ & & 165 & $3326 \pm 386$ & \\
\hline Heterozygous & 253 & $3238 \pm 386$ & 0,02 & 236 & $3236 \pm 394$ & 0,02 \\
\hline \multirow[t]{3}{*}{ Homozygous for risk allele } & 74 & $3157 \pm 366$ & 0,001 & 93 & $3161 \pm 329$ & 0,0006 \\
\hline & \multicolumn{3}{|c|}{$\begin{array}{l}\text { Mean difference (g) per newborn risk-allele } \\
\text { for rs9939609 }\end{array}$} & \multicolumn{3}{|c|}{$\begin{array}{l}\text { Mean difference }(g) \text { per newborn risk-allele } \\
\text { for rs9930506 }\end{array}$} \\
\hline & \multicolumn{2}{|c|}{ Mean $(95 \% \mathrm{Cl})$} & $P$ value & \multicolumn{2}{|c|}{ Mean $(\mathrm{g})(95 \% \mathrm{Cl})$} & $P$ value \\
\hline \multicolumn{7}{|l|}{ Various adjustments } \\
\hline Unadjusted & \multicolumn{2}{|c|}{$-78(-128 ;-28)$} & 0,002 & \multicolumn{2}{|c|}{$-83(-131 ;-36)$} & 0,0006 \\
\hline Adjusted for maternal allele & \multicolumn{2}{|c|}{$-73(-130 ;-16)$} & 0,09 & \multicolumn{2}{|c|}{$-76(-132 ;-21)$} & 0,007 \\
\hline Adjusted for maternal allele and other variables** & \multicolumn{2}{|c|}{$-56(-107 ;-5)$} & 0,03 & \multicolumn{2}{|c|}{$-55(-105 ;-6)$} & 0,03 \\
\hline Adjusted also for maternal BMI & \multicolumn{2}{|c|}{$-50(-99 ; 0)$} & 0,05 & \multicolumn{2}{|c|}{$-48(-100 ; 0)$} & 0,05 \\
\hline Adjusted also for Adjusted also for weight gain & \multicolumn{2}{|c|}{$-48(-98:+2)$} & 0,06 & \multicolumn{2}{|c|}{$-47(-95 ;+1)$} & 0,06 \\
\hline
\end{tabular}


Table 4 Associations of birth weight and maternal FTO genotypes and alleles

\begin{tabular}{|c|c|c|c|c|c|c|}
\hline & \multicolumn{6}{|c|}{ Exposure $=$ Maternal FTO SNP } \\
\hline & \multirow{2}{*}{\multicolumn{3}{|c|}{$\begin{array}{l}\text { FTO rs9939609 SNP } \\
\text { Newborn weight (g) }\end{array}$}} & \multirow{2}{*}{\multicolumn{3}{|c|}{$\begin{array}{l}\text { FTOrs9930506 SNP } \\
\text { Newborn weight (g) }\end{array}$}} \\
\hline & & & & & & \\
\hline & $\mathrm{N}$ & Mean \pm SD (g) & $P$ value vs $1^{\circ}$ group $*$ & $\mathrm{~N}$ & Mean \pm SD (g) & $P$ value vs $1^{\circ}$ group* \\
\hline \multicolumn{7}{|l|}{ Genotypes } \\
\hline Homozygous for non risk allele & 155 & $3312 \pm 383$ & & 155 & $3312 \pm 383$ & \\
\hline Heterozygous & 249 & $3227 \pm 381$ & 0,03 & & $3227 \pm 381$ & 0,03 \\
\hline \multirow[t]{3}{*}{ Homozygous for risk allele } & 90 & $3216 \pm 383$ & 0,06 & & $3216 \pm 383$ & 0,06 \\
\hline & \multicolumn{3}{|c|}{$\begin{array}{l}\text { Mean difference (g) per offspring risk-allele } \\
\text { for rs9939609 }\end{array}$} & \multicolumn{3}{|c|}{$\begin{array}{l}\text { Mean difference (g) per offspring risk-allele } \\
\text { for rs9939609 }\end{array}$} \\
\hline & Mea & $\mathrm{n}(95 \% \mathrm{Cl})$ & $P$ value & Mear & $\mathrm{n}(95 \% \mathrm{Cl})$ & $P$ value \\
\hline \multicolumn{7}{|l|}{ Various adjustments } \\
\hline Unadjusted & \multicolumn{2}{|c|}{$-53(-102 ;-4)$} & 0,03 & \multicolumn{2}{|c|}{$-45(-94 ; 5)$} & 0,08 \\
\hline adjusted for newborn allele & \multicolumn{2}{|c|}{$-13(-70 ; 43)$} & 0,65 & \multicolumn{2}{|c|}{$-10(-66 ; 47)$} & 0,20 \\
\hline adjusted for newborn allele and other variables ${ }^{* *}$ & \multicolumn{2}{|c|}{$-10(-61 ; 41)$} & 0,70 & \multicolumn{2}{|c|}{$-15(-66 ; 36)$} & 0,57 \\
\hline
\end{tabular}

*Student's T test.

${ }^{* *}$ Adjusted for sex, gestational age, panty and current smoking during pregnancy.

demonstrated a regulatory role of FTO on insulin secretion or sensitivity. In mice, induced expression of FTO enhances the first phase of glucose-induced insulin secretion in INS-1 cells of the pancreas [39]. In cultured human myotubes, FTO overexpression alters insulin signaling and increases de novo lipogenesis [40]. High-risk alleles of FTO are also associated with lower cerebrocortical insulin sensitivity [41]. The effect of FTO variants might also occur at the level of placenta where it is highly expressed [42], similar to many other tissues [9]. In animals, placental mRNA abundance of FTO is positively correlated with birth weight [43]. In humans, placental FTO expression is associated with increased fetal weight and length, and with placental weight in infants from nonprimiparous women, as well as an increased fetal-toplacental weight ratio in primiparous women. There are also other intriguing findings regarding the possible effect of FTO in maternal-fetal interactions. In the ALSPAC cohort where maternal genotypes were available [44], a maternal "risk-allele score" (combining 4 risk alleles for obesity, including FTO rs9930609) was inversely associated with gestational weight gain in the first 18 weeks of pregnancy (214.46 g/wk per allele) compared with three other risk alleles for obesity. The maternal risk allele in FTO showed the greatest trend of a negative association with birth weight $(-20.44 \mathrm{~g}$; 95\% CI: $-42.65,1.78 ; \mathrm{p}=0.07)$

Table 5 Change in weight of infants according to genotypes

\begin{tabular}{|c|c|c|c|c|c|c|c|c|}
\hline \multirow[t]{2}{*}{ FTO rs9939609 } & \multirow[b]{2}{*}{$\mathbf{N}$} & \multicolumn{2}{|l|}{ Newborns with TT genotype } & \multicolumn{2}{|l|}{ Newborns with TA genotype } & \multirow{2}{*}{$\begin{array}{l}\text { Newborns with AA genotype } \\
\text { mean (g) SD }\end{array}$} & \multicolumn{2}{|c|}{ Statistic (P values)* } \\
\hline & & mean (g) SD & $\mathbf{N}$ & mean (g) SD & $\mathbf{N}$ & & G2 vs G1 & G3 vs G1 \\
\hline At birth & 167 & $3314 \pm 378$ & 253 & $3238 \pm 386$ & 74 & $3157 \pm 366$ & 0,05 & 0,00 \\
\hline 3 months & 31 & $5358 \pm 404$ & 60 & $5467 \pm 627$ & 13 & $5271 \pm 593$ & 0,38 & 0,58 \\
\hline 6 months & 25 & $7199 \pm 494$ & 54 & $7374 \pm 635$ & 13 & $6989 \pm 618$ & 0,23 & 0,26 \\
\hline 9 months & 31 & $9242 \pm 491$ & 55 & $9058 \pm 779$ & 14 & $9058 \pm 352$ & 0,24 & 0,21 \\
\hline 1 year & 127 & $10706 \pm 753$ & 190 & $10781 \pm 917$ & 54 & $10738 \pm 550$ & 0,44 & 0,78 \\
\hline \multirow[t]{2}{*}{ FTO rs9930506 } & & \multicolumn{2}{|l|}{ Newborns with AA genotype } & \multicolumn{2}{|l|}{ Newborns with AG genotype } & Newborns with GG genotype & \multicolumn{2}{|c|}{ Statistic (P values) } \\
\hline & $\mathbf{N}$ & mean $(\mathbf{g})$ SD & $\mathbf{N}$ & mean (g) SD & $\mathbf{N}$ & mean (g) SD & G2 vs G1 & G3 vs $\mathrm{G} 1$ \\
\hline At birth & 165 & $3326 \pm 386$ & 236 & $3236 \pm 394$ & 93 & $3161 \pm 329$ & 0,00 & 0,00 \\
\hline 3 months & 30 & $5325 \pm 386$ & 56 & $5496 \pm 648$ & 18 & $5283 \pm 545$ & 0,19 & 0,76 \\
\hline 6 months & 25 & $7023 \pm 358$ & 50 & $7343 \pm 685$ & 17 & $7164 \pm 656$ & 0,34 & 0,80 \\
\hline 9 months & 30 & $9158 \pm 517$ & 51 & $9059 \pm 787$ & 19 & $9197 \pm 423$ & 0,54 & 0,78 \\
\hline 1 year & 126 & $10798 \pm 761$ & 173 & $10635 \pm 893$ & 72 & $10937 \pm 675$ & 0,10 & 0,20 \\
\hline
\end{tabular}

*Student's T test. 
[44]. Fetal FTO may participate either in the control of fetal weight gain or in the partitioning between maternal storage, placental development, and fetal growth. Interactions between maternal genetics and fetal metabolism or reciprocally have been previously demonstrated for lipoprotein metabolism $[45,46]$. However, how such interactions occur and an explanation for the inverse relation between the risk allele for obesity and low birth weight are still speculative at this stage.

We recognize that our study has some limitations. First, the associations observed in our study could be false positives. A false positive association is frequently caused by the confounding effect of population stratification when ethnicity or geographic origin is associated with the phenotype and genotype. We attempted to control for this type of bias by verifying and adjusting for the origin (especially Italian origin). Our sample size is small compared with the majority of genetic association studies. This resulted in a lower power to detect any associations with a high level of statistical significance. Calculation of statistical power using a mean difference per allele of $50 \mathrm{~g}$ showed that we had a $44 \%$ power to detect an association. Finally, birth weight is a simple measure that does not discern between fat mass and other components. Future studies need to investigate a more precise measure of fat mass in newborns using total body electric conductivity, dual energy $\mathrm{x}$-ray absorptiometry, or air displacement plethysmography [47].

\section{Conclusions}

In conclusion, the present study investigated 494 newborns with well-documented confounding factors that affect birth weight. After exclusion of pathological situations affecting birth weight, the FTO risk allele for obesity showed a significant, inverse association with birth weight. This association remained significant after correction for confounding factors and maternal FTO variants. This observation is compatible with the notion that genetic variants leading to obesity in later life may cause lower weight in fetal life, and supports a role for FTO in early growth.

\section{Competing interests}

The authors declare that they have no competing interests.

\section{Authors' contributions}

OS conceived the study, participated in its design, performed the statistical analysis, and drafted the manuscript. ET carried out the molecular genetic analyses. PFG participated in the design of the study. All authors read and approved the final manuscript.

\section{Acknowledgements}

We are extremely grateful to all of the mothers who took part in our study, and to the nurses and midwives for their help in recruiting them. We thank Sylvie Mabille, Monique Bruniau, and Murer Matteo for their technical assistance in collecting data and performing the genetic analyses.

\section{Author details}

'Center for Medical Research at Jolimont, 159 Rue Ferrer, B-7100 Haine Saint-Paul, Belgium. ${ }^{2}$ Department of Internal Medicine, Centre Hospitalier Jolimont-Lobbes, 159 Rue Ferrer, B-7100 Haine Saint-Paul, Belgium.

${ }^{3}$ Department of Obstetrics and Gynecology, Centre Hospitalier

Jolimont-Lobbes, 159 Rue Ferrer, B-7100 Haine Saint-Paul, Belgium.

Received: 27 January 2014 Accepted: 5 December 2014

Published online: 24 December 2014

\section{References}

1. Barker DJP, Winter PD, Osmond C, Margetts B, Simmonds SJ: Weight in infancy and death from ischaemic heart disease. Lancet 1989, 2:577-580.

2. Curhan GC, Willett WC, Rimm EB, Spiegelman D, Ascherio AL, Stampfer MJ: Birthweight and adult hypertension, diabetes mellitus and obesity in US men. Circulation 1996, 94:3246-3250.

3. Barker DJP, Hales CN, Fall CHD, Osmond C, Phipps K, Clark PMS: Type 2 (non-insulin dependent) diabetes mellitus, hypertension and hyperlipidemia (syndrome $\mathrm{X}$ ): relation to reduced fetal growth. Diabetologia 1993, 36:62-67.

4. Harder T, Rodekamp E, Schellong K, Dudenhausen JW, Plagemann A: Birthweight and subsequent risk of type 2 diabetes: a meta-analysis. Am J Epidemiol 2007, 165:849-857.

5. Mu M, Wang SF, Sheng J, Zhao Y, Li HZ, Hu CL, Tao FB: Birthweight and subsequent blood pressure: a meta-analysis. Arch Cardiovasc Dis 2012, 105:99-113

6. Rabadán-Diehl C, Nathanielsz P: From Mice to Men: research models of developmental programming. J Dev Orig Health Dis 2013, 4:3-9.

7. Desai M, Li T, Ross MG: Hypothalamic neurosphere progenitor cells in low birth-weight rat newborns: neurotrophic effects of leptin and insulin. Brain Res 2011, 1378:29-42.

8. Hattersley AT, Tooke JE: The fetal insulin hypothesis: an alternative explanation of the association of low birthweight with diabetes and vascular disease. Lancet 1999, 353:1789-1792.

9. Frayling TM, Timpson NJ, Weedon MN, Zeggini E, Freathy RM, Lindgren CM, Perry JR, Elliott KS, Lango H, Rayner NW, Shields B, Harries LW, Barrett JC, Ellard S, Groves CJ, Knight B, Patch AM, Ness AR, Ebrahim S, Lawlor DA, Ring SM, Ben-Shlomo Y, Jarvelin MR, Sovio U, Bennett AJ, Melzer D, Ferrucci L, Loos RJ, Barroso I, Wareham NJ, et al: A common variant in the FTO gene is associated with body mass index and predisposes to childhood and adult obesity. Science 2007, 316:889-894.

10. Loos RJ, Bouchard C: FTO: the first gene contributing to common forms of human obesity. Obes Rev 2008, 9:246-250.

11. Liu C, Mou S, Cai Y: FTO Gene Variant and Risk of Overweight and Obesity among Children and Adolescents: a Systematic Review and Meta-Analysis. PLoS One 2013, 8:e82133.

12. Lopez-Bermejo A, Petry CJ, Diaz M, Sebastiani G, de Zegher F, Dunger DB, Ibáñez $\mathrm{L}$ : The association between the FTO gene and fat mass in humans develops by the postnatal age of two weeks. J Clin Endocrinol Metab 2008, 93:1501-1505.

13. Hakanen M, Raitakari OT, Lehtimäki T, Peltonen N, Pahkala K, Sillanmäki L, Lagström H, Viikari J, Simell O, Rönnemaa T: FTO genotype is associated with body mass index after the age of seven years but not with energy intake or leisure-time physical activity. J Clin Endocrinol Metab 2009, 94:1281-1287.

14. Cauchi S, Stutzmann F, Cavalcanti-Proenca C, Durand E, Pouta A, Hartikainen AL, Marre M, Vol S, Tammelin T, Laitinen J, Gonzalez-Izquierdo A, Blakemore Al, Elliott P, Meyre D, Balkau B, Järvelin MR, Froguel P: Combined effects of MC4R and FTO common genetic variants on obesity in European general populations. J Mol Med 2009, 87:537-546.

15. Scuteri A, Sanna S, Chen WM, Uda M, Albai G, Strait J, Najjar S, Nagaraja R, Orrú M, Usala G, Dei M, Lai S, Maschio A, Busonero F, Mulas A, Ehret GB, Fink AA, Weder AB, Cooper RS, Galan P, Chakravarti A, Schlessinger D, Cao A, Lakatta E, Abecasis GR: Genome-wide association scan shows genetic variants in the FTO gene are associated with obesity-related traits. PLOS Genet 2007, 3:e115.

16. Sentinelli F, Incani M, Coccia F, Capoccia D, Cambuli VM, Romeo S, Cossu E, Cavallo MG, Leonetti F, Baroni MG: Association of FTO polymorphisms with early age of obesity in obese Italian subjects. Exp Diabetes Res 2012, 2012:872176. 
17. Armitage P, Berry G: Statistical methods in medical research. 2nd edition. London, UK: Blackwell Scientific Publications; 1987.

18. Peeters A, Beckers S, Verrijken A, Roevens P, Peeters P, Van Gaal L, Van Hul W: Variants in the FTO gene are associated with common obesity in the Belgian population. Mol Genet Metab 2008, 93:481-484.

19. Mitchell EA, Robinson E, Clark PM, Becroft DM, Glavish N, Pattison NS, Pryor JE, Thompson JM, Wild CJ: Maternal nutritional risk factors for small for gestational age babies in a developed country: a casecontrol study. Arch Dis Child Fetal Neonatal Ed 2004, 89:F431-F435.

20. Morgan AR, Thompson J, Murphy R, Black PN, Lam W-J, Ferguson LR, Mitchell EA: Obesity and diabetes genes are associated with being born small for gestational age: Results from the Auckland Birthweight Collaborative study. BMC Med Genetics 2010, 11:125.

21. Freathy RM, Weedon MN, Bennett A, Hypponen E, Relton CL, Knight B, Shields B, Parnell KS, Groves CJ, Ring SM, Pembrey ME, Ben-Shlomo Y, Strachan DP, Power C, Jarvelin MR, McCarthy MI, Davey Smith G, Hattersley AT, Frayling TM: Type 2 diabetes TCF7L2 risk genotypes alter birthweight: a study of 24,053 individuals. Am J Hum Genet 2007, 80:1150-1161.

22. Freathy RM, Bennett AJ, Ring SM, Shields B, Groves CJ, Timpson NJ, Weedon MN, Zeggini E, Lindgren CM, Lango $H$, Perry JR, Pouta A, Ruokonen A, Hyppönen E, Power C, Elliott P, Strachan DP, Järvelin MR, Smith GD, McCarthy MI, Frayling TM, Hattersley AT: Type 2 Diabetes Risk Alleles are Associated with Reduced Size at Birth. Diabetes 2009, 58:1428-1433.

23. Zhao J, Li M, Bradfield JP, Wang K, Zhang H, Sleiman P, Kim CE, Annaiah K, Glaberson W, Glessner JT, Otieno FG, Thomas KA, Garris M, Hou C, Frackelton EC, Chiavacci RM, Berkowitz RI, Hakonarson H, Grant SF: Examination of type 2 diabetes loci implicates CDKAL1 as a birthweight gene. Diabetes 2009, 58:2414-2418.

24. Pulizzi N, Lyssenko V, Jonsson A, Osmond C, Laakso M, Kajantie E, Barker DJ, Groop LC, Eriksson JG: Interaction between prenatal growth and high-risk genotypes in the development of type 2 diabetes. Diabetologia 2009, 52:825-829.

25. Freathy RM, Mook-Kanamori DO, Sovio U, Prokopenko I, Timpson NJ, Berry DJ, Warrington NM, Widen E, Hottenga JJ, Kaakinen M, Lange LA, Bradfield JP, Kerkhof M, Marsh JA, Mägi R, Chen CM, Lyon HN, Kirin M, Adair LS, Aulchenko YS, Bennett AJ, Borja JB, Bouatia-Naji N, Charoen P, Coin L, Cousminer DL, de Geus EJ, Deloukas P, Elliott P, Evans DM, Froguel P, et al: Variants in ADCY5 and near CCNL1 are associated with fetal growth and birthweight. Nat Genet 2010, 42:430-435.

26. Cauchi S, Meyre D, Choquet H, Deghmoun S, Durand E, Gaget S, Lecoeur C, Froguel P, Levy-Marchal C: TCF7L2 rs7903146 variant does not associate with smallness for gestational age in the French population. BMC Med Genet 2007, 8:37

27. Mook-Kanamori DO, de Kort SW, van Duijn CM, Uitterlinden AG, Hofman A, Moll HA, Steegers EA, Hokken-Koelega AC, Jaddoe WW: Type 2 diabetes gene TCF7L2 polymorphism is not associated with fetal and postnatal growth in two birth cohort studies. BMC Med Genet 2009, 10:67.

28. Andreasen $\mathrm{CH}$, Stender-Petersen $\mathrm{KL}$, Mogensen MS, Torekov SS, Wegner L, Andersen G, Nielsen AL, Albrechtsen A, Borch-Johnsen K, Rasmussen SS, Clausen JO, Sandbaek A, Lauritzen T, Hansen L, Jørgensen T, Pedersen O, Hansen T: Low physical activity accentuates the effect of the FTO rs9939609 polymorphism on body fat accumulation. Diabetes 2008, 57:95-101.

29. Elks CE, Loos RJF, Sharp SJ, Langenberg C, Ring SM, Timpson NJ, Ness AR, Davey Smith G, Dunger DB, Wareham NJ, Ong KK: Genetic markers of adult obesity risk are associated with greater early infancy weight gain and growth. PLoS Med 2010, 7:e1000284.

30. Hardy R, Wills AK, Wong A, Elks CE, Wareham NJ, Loos RJ, Kuh D, Ong KK: Life course variations in the associations between FTO and MC4R gene variants and body size. Hum Mol Genet 2010, 19:545-552.

31. Mook-Kanamori DO, Marsh JA, Warrington NM, Taal HR, Newnham JP, Beilin U, Lye SJ, Palmer L, Hofman A, Steegers EA, Pennell CE, Early Growth Genetics Consortium, Jaddoe W: Variants near CCNL1/LEKR1 and in ADCY5 and fetal growth characteristics in different trimesters. $J$ Clin Endocrinol Metab 2011, 96(5):E810-5.

32. Kilpelainen TO, den Hoed M, Ong KK, Grontved A, Brage S, Early Growth Genetics Consortium, Jameson K, Cooper C, Khaw KT, Ekelund U, Wareham $\mathrm{NJ}$, Loos RJ: Obesity-susceptibility loci have a limited influence on birthweight: a meta-analysis of up to 28,219 individuals. Am J Clin Nutrit 2011, 93:851-860.

33. Wilcox M, Gardosi J, Mongelli M, Ray C, Johnson I: Birthweight from pregnancies dated by ultrasonography in a multicultural British population. BMJ 1993, 307:588-591.

34. Wardle J, Carnell S, Haworth CMA, Faroogi IS, O'Rahilly S, Plomin R: Obesity associated genetic variation in FTO is associated with diminished satiety. J Clin Endocrinol Metab 2008, 93:3640-3643.

35. Tanofsky-Kraff M, Han JC, Anandalingam K, Shomaker LB, Columbo KM, Wolkoff LE, Kozlosky M, Elliott C, Ranzenhofer LM, Roza CA, Yanovski SZ, Yanovski JA: The FTO gene rs9939609 obesity-risk allele and loss of control over eating. Am J Clin Nutr 2009, 90:1483-1488.

36. Timpson NJ, Emmett PM, Frayling TM, Rogers I, Hattersley AT, McCarthy MI, Davey Smith G: The fat mass-and obesity-associated locus and dietary intake in children. Am J Clin Nutr 2008, 88:971-978.

37. Fowden AL: The role of insulin in fetal growth. Early Hum Dev 1992, 29:177-181.

38. Damasceno DC, Sinzato YK, Bueno A, Netto AO, Dallaqua B, Gallego FQ, lessi IL, Corvino SB, Serrano RG, Marini G, Piculo F, Calderon IM, Rudge MV: Mild diabetes models and their maternal-fetal repercussions. J Diabetes Res 2013, 2013:473-475.

39. Russell MA, Morgan NG: Conditional expression of the FTO gene product in rat INS-1 cells reveals its rapid turnover and a role in the profile of glucose-induced insulin secretion. Clin Sci (Lond) 2011, 120:403-413.

40. Bravard A, Lefai E, Meugnier E, Pesenti S, Disse E, Vouillarmet J, Peretti N, Rabasa-Lhoret R, Laville M, Vidal H, Rieusset J: FTO is increased in muscle during type 2 diabetes, and its overexpression in myotubes alters insulin signaling, enhances lipogenesis and ROS production, and induces mitochondrial dysfunction. Diabetes 2011, 60:258-268.

41. Tschritter O, Preissl H, Yokoyama Y, Machicao F, Häring HU, Fritsche A: Variation in the FTO gene locus is associated with cerebrocortical insulin resistance in humans. Diabetologia 2007, 50:2602-2603.

42. Bassols J, Prats-Puig A, Vázquez-Ruíz M, García-González MM, MartínezPascual M, Avellí P, Martínez-Martínez R, Fàbrega R, Colomer-Virosta C, Soriano-Rodríguez P, Díaz M, de Zegher F, Ibánez L, López-Bermejo A: Placental FTO expression relates to fetal growth. Int J Obes (Lond) 2010, 34:1365-1370.

43. Sebert SP, Hyatt MA, Chan LL, Yiallourides M, Fainberg HP, Patel N, Sharkey D, Stephenson T, Rhind SM, Bell RC, Budge H, Gardner DS, Symonds ME: Influence of prenatal nutrition and obesity on tissue specific fat mass and obesity-associated (FTO) gene expression. Reproduction 2010, 139:265-274.

44. Lawlor DA, Fraser A, Macdonald-Wallis C, Nelson SM, Palmer TM, Davey Smith G, Tilling K: Maternal and offspring adiposity-related genetic variants and gestational weight gain. Am J Clin Nutr 2011, 94:149-155.

45. Descamps OS, Bruniau M, Guilmot PF, Tonglet R, Heller FR: Lipoprotein concentrations in newborns are associated with allelic variations in their mothers. Atherosclerosis 2004, 172:287-298.

46. Descamps OS, Bruniaux M, Guilmot PF, Tonglet R, Heller FR: Lipoprotein metabolism of pregnant women is associated with both their genetic polymorphisms and those of their newborn children. J Lipid Res 2005, 46:2405-2414.

47. Deierlein AL, Thornton J, Hull H, Paley C, Gallagher D: An anthropometric model to estimate neonatal fat mass using air displacement plethysmography. Nutr Metab (Lond) 2012, 9:21.

\section{Submit your next manuscript to BioMed Central and take full advantage of:}

- Convenient online submission

- Thorough peer review

- No space constraints or color figure charges

- Immediate publication on acceptance

- Inclusion in PubMed, CAS, Scopus and Google Scholar

- Research which is freely available for redistribution 